
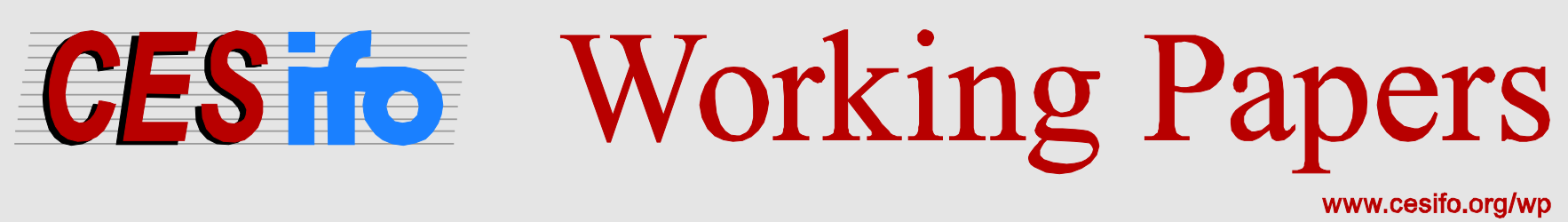

\title{
Do Dividend Taxes Affect Corporate Investment?
}

\author{
Annette Alstadsæter \\ Martin Jacob \\ Roni Michaely
}

CESIFO WORKING PAPER NO. 4931

CATEgory 1: PubliC FinANCE

ORIGINAL VERSION: AUguST 2014

THIS VERSION: NOVEMBER 2014

An electronic version of the paper may be downloaded

- from the SSRN website:

- from the RePEc website:

- from the CESifo website:

WWW.SSRN.com

www.RePEc.org

www.CESifo-group.org/wp

\section{CESifo}




\title{
Do Dividend Taxes Affect Corporate Investment?
}

\begin{abstract}
We test whether dividend taxes affect corporate investments. We exploit Sweden's 2006 dividend tax cut of 10 percentage points for closely held corporations and five percentage points for widely held corporations. Using rich administrative panel data and triple-difference estimators, we find that this dividend tax cut affects allocation of corporate investment. Cashconstrained firms increase investment after the dividend tax cut relative to cash-rich firms. Reallocation is stronger among closely held firms that experience a larger tax cut. This result is explained by higher nominal equity in cash-constrained firms and by higher dividends in cash-rich firms after the tax cut. The heterogeneous investment responses imply that the dividend tax cut raises efficiency by improving allocation of investment.
\end{abstract}

JEL-Code: G300, G310, H250.

Keywords: investment, dividend taxation, private firms.

Annette Alstadscer
Institute of Health and Society
University of Oslo
PO Box 1089 Blindern
Norway - 0317 Oslo
annette.alstadsater@medisin.uio.no

Annette Alstadsceter

University of Oslo

PO Box 1089 Blindern

annette.alstadsater@medisin.uio.no

\author{
Martin Jacob* \\ WHU - Otto Beisheim School \\ of Management \\ Burgplatz 2 \\ Germany - 56179 Vallendar \\ martin.jacob@whu.edu
}

\author{
Roni Michaely \\ Johnson Graduate School of Management \\ Cornell University \\ 114 East Ave \\ USA - Ithaca, NY 14850 \\ RM34@Cornell.edu
}

*corresponding author

This draft: November 2014

We are grateful to Alan Auerbach, Seppo Kari, Christian Keuschnigg, Jan Södersten, Kelly Wentland, and seminar participants at the 2014 Trans-Atlantic Public Economics Seminar in Vienna and the Oslo Fiscal Studies 2014 Workshop on Taxing Capital Income, for helpful comments and suggestions. 


\section{Introduction}

There are contrasting views on whether dividend taxes affect corporate investment. Traditional models of dividend taxation assume that the cost of capital of firms, and thus corporate investment, depends on the level of dividend taxation (Harberger 1962, 1966, Feldstein 1970, Poterba and Summers 1985). In contrast, the new view of dividend taxation assumes that investments are funded by retained earnings rather than new equity (King 1977, Auerbach 1979, Bradford 1981). Chetty and Saez (2010) argue that a dividend tax cut has heterogeneous effects on the allocation of investment: Firms with excess cash holdings invest less while cash-constrained firms invest more following a dividend tax cut. Empirical evidence is, however, mixed. Becker, Jacob, and Jacob (2013) show that dividend taxes affect the allocation of investment across firms, using an international sample of listed firms. In contrast, Yagan (2013) shows that for unlisted U.S. firms, there is no change in corporate investment around the 2003 tax $^{\text {act. }^{1}}$

This raises the question whether the theoretical predictions hold only for listed firms. Listed U.S. firms exhibit behavior consistent with either the new view or the traditional view (Auerbach and Hassett 2002). However, little is known empirically about dividend tax effects on the investments of unlisted corporations. We contribute to this discussion by showing empirically that dividend taxation can have heterogeneous effects on corporate investments by unlisted firms. Unlisted firms represent a very important part of the economy in many OECD countries (e.g., Michaely and Roberts 2012, Yagan 2013). In Sweden, over 99\% of all firms (corporations and unincorporated businesses) are unlisted. Our data sample comprises all Swedish corporations that employ over $85 \%$ of all private sector workers and that account for about $90 \%$ of private sector investment.

\footnotetext{
For a sample of listed U.S. firms, Campbell, Chyz, Dhaliwal, and Schwartz (2013) find evidence of investment responses to the 2003 tax act consistent with the old and the new view of dividend taxation.
} 
We use a quasi-experimental setting to analyze the effect of a dividend tax cut on corporate investment by unlisted firms. In 2006, Sweden cut its dividend taxes for shareholders in unlisted corporations. The magnitude of the cut depends on the ownership structure of the firm: a 5-percentage-point cut for widely held corporations and a 10-percentage-point cut for closely held corporations. According to Chetty and Saez (2010, p. 27), such "a dividend tax cut raises efficiency by improving the allocation of capital: firms with excess cash holdings invest less following a tax cut, while cash-constrained firms invest more.” We utilize rich administrative panel data for all Swedish corporations over the period 2000-2011 to generate empirical evidence for the Chetty and Saez theoretical result. We expect investment responses for both closely held and widely held corporations, however, ceteris paribus, the response is expected to be greater for closely held corporations than for widely held corporations.

Our empirical identification strategy of testing the dividend tax effect on the allocation of investments across firms is threefold. First, we use a difference-in-difference (DD) approach to test whether the 2006 dividend tax cut increases investment by cash-constrained closely held corporations relative to closely held corporations with internal resources. We use the average cash-to-assets ratio over the pre-reform period 2002-2005 as the measure of cash constraints. This ensures that our measure for availability of internal funds is exogenous to the reform. Second, we run the same DD analysis for widely held corporations. Finally, we exploit the difference in the dividend tax cut across firms and compare the investment response between closely held corporations and widely held corporations using a differencein-difference-in-difference (DDD) approach.

Our empirical results show that, relative to cash-rich firms, cash-constrained firms increase their investments after the dividend tax cut. For closely held corporations, for which dividend taxes decreased by 10 percentage points, or $33 \%$ of the pre-reform level, the relative investment effect is $36 \%$ of the average investment in our sample. For widely held 
corporations, which experienced a tax rate decrease of five percentage points, or $17 \%$ of the pre-reform level, the relative investment effect is $16.4 \%$ of the sample average. These estimates account for other observable firm characteristics, industry-year fixed effects, and firm fixed effects and indicate that the implied elasticity is close to one. Since the tax cut is larger for closely held corporations than the dividend tax cut for widely held corporations, the relative investment effects are expected to be greater for closely held corporations. We find exactly this result. The magnitude of the DDD estimate corresponds to the relative dividend tax cut: We obtain a DD coefficient of 0.1584 for closely held corporations (10-percentagepoint tax cut) and a DD coefficient of 0.0713 for widely held corporations (5-percentage-point tax cut). The DDD estimate of 0.0719 reflects the relative dividend tax cut difference of 5 percentage points. The result indicates that a five percentage point tax cut—a relative decrease in the tax rate of $17 \%$ - decreases the investment difference by $16.6 \%$ of the average investment. Investment is shifted from cash-rich to cash-poor firms after a dividend tax cut.

There are two potential explanations for the observed investment reallocation effect. First, following a dividend tax cut, we would expect cash-constrained firms to raise more equity to finance investments. In a DD framework, we test whether the dividend tax cut is associated with increased nominal equity among previously cash-constrained firms. Our results support this explanation: Relative to cash-rich firms, the nominal equity-to-assets ratio increases in cash-constrained corporations after tax reform by 1.5 percentage points—about $11 \%$ of the sample average. We further show empirically that, relative to cash-rich firms, cash-poor firms decrease their debt-to-equity ratio around the tax reform. This implies that cash-constrained firms rely more on the external equity channel than on external debt to fund additional projects after the tax cut. A second explanation relates to the use of funds. Following a dividend tax cut, Chetty and Saez (2010) predict that cash-rich firms increase dividend distributions. We find exactly this result for the sample of closely held corporations for which 
we have data on dividend payouts. In sum, the decrease in the investment difference can be explained by higher equity issuance from cash-poor firms and by higher dividend payouts from cash-rich firms.

Our paper contributes to the literature in several ways. We provide direct empirical evidence that dividend tax reforms generate heterogeneous investment responses, as predicted by theory (see, e.g., Feldstein 1970, Auerbach 1979, Poterba and Summers 1985, Chetty and Saez 2010). Our results imply that dividend taxes not only affect dividend payout decisions (see, e.g., Poterba 2004, Chetty and Saez 2005, Jacob, Michaely and Alstadsæter 2014) and equity prices (see, e.g., Auerbach and Hassett 2006, Chetty, Rosenberg, and Saez 2007), but also corporate investments. High dividend taxation appears to lock in funds in cash-rich firms, more so than in cash-constrained firms that need more costly external financing. Dividend taxation effectively creates a wedge between the cost of internal equity and the cost of external equity. When dividend taxes are decreased, allocation of investment is improved, and thus efficiency increases. Overall, our empirical results are consistent with the theoretical results of Chetty and Saez (2010) that dividend taxation creates a first-order deadweight cost.

The remainder of this paper proceeds as follows. Section 2 describes Sweden's 2006 tax reform. Section 3 discusses how the reform changed investment incentives, and we present three testable hypotheses. Section 4 presents the data, while the empirical strategy and results are presented in Section 5. Finally, Section 6 sets forth our conclusions.

\section{Swedish Dividend Taxation and the 2006 Reform}

Sweden has a dual income tax, with a proportional tax on capital income and progressive taxation of labor income. During the 2000-2005 period, the corporate income tax rate was $28 \%$ and dividends were taxed at $30 \%$ at the shareholder level. Dividends to active 
shareholders in closely held corporations ${ }^{2}$ were taxed at a rate of $30 \%$ if they were within a dividend allowance. Dividends exceeding the dividend allowance were taxed as wage income. $^{3}$

For many years, there was an ongoing discussion on how to change the calculation method for the dividend allowance to make it more beneficial for small business owners. However, policy makers could not agree on a compromise. In 2005, an expert committee presented a report that proposed changes in the calculation of the dividend allowance, which then were implemented by January 1, 2006. ${ }^{4}$ In late 2005, a last minute tax relief of SEK 1 billion was granted and the committee decided to spend these funds on dividend tax rate reductions. ${ }^{5}$ The tax relief was motivated to spur entrepreneurship and investment in general and not directly targeted at improving investment allocation across corporations. Since this dividend tax reduction was not included in the initial reform discussions, it was not anticipated by firms. The reform was implemented permanently and, due to Sweden's history of broad and longlasting tax reforms, it is reasonable to assume that the reform was also perceived as permanent by corporations and owners. ${ }^{6}$ The 2006 reform implemented the following three important changes:

1) Dividend tax rate for shareholders in unlisted, widely held corporations was reduced by 5 percentage points to $25 \%$.

2 A corporation is considered closely held if four or fewer persons own more than half the votes. Immediate family members count as one person. All active owners count as only one person when a corporation is classified as closely or widely held. A shareholder is considered active if the shareholder contributes to a considerable extent in the profit generation of the corporation.

3 The marginal income tax on wage income ranges from $31 \%$ to $56 \%$.

4 In 1999, an expert group was appointed to evaluate the calculation rules for the dividend allowance; it delivered a report in 2002. The report's suggestions were not implemented. A new expert group was appointed mid-2004, which reported in early 2005. Based on this report, the Government presented its proposal for changes in late 2005. These changes came into effect in January 2006. For more details and references on this process, see Alstadsæter and Jacob (2012).

5 Edin et al. (2005), Government Bills 2004/05:1, 2005/06:40, and 2006/07:1.

6 The dual income tax was introduced in Sweden in 1991, followed by Norway in 1992 and Finland in 1993, and is still in place in Sweden and the other Scandinavian countries. Great emphasis is placed on the robustness and predictability of the tax system. In other words, there is a tradition that tax rules are sticky once they are introduced. 
2) Dividend tax rate for active shareholders in closely held corporations was reduced by 10 percentage points to $20 \%$ for dividends within the dividend allowance.

3) The imputed dividend allowance for active shareholders in closely held corporations was substantially increased.

In sum, the 2006 tax reform reduced dividend taxes by 10 percentage points for owners of closely held corporations and by five percentage points for owners of unlisted, widely held corporations. ${ }^{7}$ In our empirical analysis, we exploit both the tax rate changes over time and the difference in the tax rate change between closely held and widely held corporations. Table 1 summarizes tax rates and changes around the reform.

\section{[Insert Table 1 about here]}

\section{Investment Incentives and the 2006 Reform}

Theory predicts that a dividend tax has heterogeneous effects on investments across firms, depending on their marginal source of finance. The "old view" assumes that firms require external equity to fund investments (Harberger 1962, 1966, Feldstein 1970, Poterba and Summers 1985). Under this view, dividend taxation affects the cost of equity and consequently has an effect on corporate investment. The "new view" of dividend taxation assumes that firms have internal funds to invest (King 1977, Auerbach 1979, Bradford 1981). In this case, dividend taxes have no effect on marginal investment.

However, firms are heterogeneous in their ability to internally fund investments. To illustrate intuitively how the 2006 dividend tax cut affects investment across different types of corporations, we use a highly simplified and stylized one-period model (e.g., Lewellen and Lewellen 2006, Becker, Jacob, and Jacob 2013). ${ }^{8}$ The firm has the opportunity to invest USD 1 in year $t$. If the firm invests in the project, it receives a rate of return, $r$, net of corporate

See Alstadsæter and Jacob (2012) for a thorough description of the Swedish tax system and the 2006 tax reform.

8 We would obtain similar predictions in more complex models that include agency costs (Chetty and Saez 2010) or intertemporal aspects (Korinek and Stiglitz 2009). 
taxes. We assume that the firm distributes all profits in year $t+1$ as dividends. Dividends are subject to dividend taxation at tax rate $t^{\text {Div }}$. Repaying nominal equity to shareholders has no tax consequences. ${ }^{9}$ A firm chooses to undertake an investment if the after-tax return exceeds the net return of an alternative investment outside the firm. The required rate of return depends on which is the marginal source of funds for the corporation: new equity (Case 1) or retained earnings (Case 2).

\subsection{Case 1: New Equity as the Marginal Source of Finance}

If a cash-constrained firm is unable to finance new investments with internal capital, we assume that it relies on external equity to finance new investments. This can, for example, apply to small and young firms. Investors decide between supplying the firm the required equity or pursuing an alternative investment. The firm needs to raise USD 1 of new equity in year $t$ to make an investment that produces an after-corporate tax profit of $(1+r)$ in year $t+1$. The equity component of this USD 1 is tax exempt and the investor pays dividend taxes on the return, $r$. In sum, the investor receives $1+r \cdot\left(1-t^{D i v}\right)$ after investing. Alternatively, the investor can directly invest in bonds instead of investing in the firm. In this case, the investor obtains $1+i$, where $i$ is the nominal after-tax interest rate. Therefore, the required rate of return for investing new equity in the firm becomes $r_{r e q}^{N E}=i \cdot \frac{1}{1-t^{D i v}}$. An increase in the dividend tax raises the required rate of $\operatorname{return}^{10}: \frac{\partial r_{r e q}^{N E}}{\partial t^{D i v}}=t^{D i v} \cdot i \cdot \frac{1}{\left(1-t^{D i v}\right)^{2}}>0$.

For cash-constrained firms, a reduction in the dividend tax leads to increased investment as the marginal cost of external capital decreases. This simple model implies that cash-

$9 \quad$ We implicitly assume share repurchases are taxed at the same rate as is the case in Sweden. Hence, using share repurchases to distribute the final profit in $t=1$ would yield similar results.

10 Other theoretical approaches also derive the prediction that a dividend tax cut may result in a reduction in the required rate of return. In a small open economy, Apel and Södersten (1999), Lindhe and Södersten (2012), and Jacob and Södersten (2013) argue that a dividend tax cut for domestically held corporations can result in reduced required rate of return. 
constrained firms would increase investment in response to the 2006 Swedish dividend tax cut.

\subsection{Case 2: Retained Earnings as the Marginal Source of Finance}

A cash-rich firm chooses whether to distribute retained earnings as dividends to shareholders or to invest in the firm's capital stock. The firm chooses between an immediate payout and reinvestment in the firm. In the case of immediate payout, shareholders receive a new dividend of $\left(1-t^{\text {Div }}\right)$. Assuming that these proceeds are invested in a risk-free bond, investors yield a net-of-tax return of $i$. In year $t+1$, the investor obtains a final value of $(1+i) \cdot\left(1-t^{D i v}\right)$. Alternatively, the firm can retain USD 1 and reinvest. In this case, the firm distributes $(1+r)$ to the shareholder in year $t+1$. After paying dividend taxes, the investor has a net wealth of $(1+r) \cdot\left(1-t^{\text {Div }}\right)$. Comparison of the net proceeds of both alternatives yields a required rate of return for an investment financed by retained earnings of $r_{r e q}^{R E}=i$. This required rate of return does not depend on the dividend tax, as $\frac{\partial r_{r e q}^{R E}}{\partial t^{D i v}}=0$.

A cash-rich firm can fund investments internally and will invest in new projects as long as the after-tax return exceeds the after-tax return to bonds. For these firms, a reduction in the dividend tax has no effect on investment. Our highly stylized illustration implies that we would not find an investment response among cash-rich firms to the 2006 Swedish dividend tax cut. While the Chetty and Saez (2010) model produces a similar prediction for cashconstrained firms, cash-rich firms are expected to decrease investment and to increase dividend payout. In either case, allocation of investment would improve as the difference in investment between cash-rich and cash-constrained firms decreases.

\subsection{Empirical Predictions}

We next derive empirical predictions from these two cases. Our empirical predictions focus on the difference in investment between these two sets of firms, cash-constrained and cash- 
rich firms. A dividend tax cut is expected to reduce the wedge between the required rate of return of cash-poor and cash-rich firms. We therefore argue that a dividend tax cut-apart from any level effects-reduces the difference between investments of cash-poor and cashrich firms. This conjecture should hold separately for both closely held and widely held corporations. This would effectively improve the allocation of investment across firms and thereby raise efficiency (Chetty and Saez 2010). We also expect this allocation effect to be stronger for closely held firms than for widely held firms. The dividend tax cut for closely held firm owners is twice the magnitude as for widely held corporation owners. Based on these considerations, we formulate the following three hypotheses for the effect of the 2006 tax reform on allocation of investment:

Hypothesis 1: The 2006 dividend tax cut decreases the difference in investment between cash-constrained and cash-rich closely held corporations.

Hypothesis 2: The 2006 dividend tax cut decreases the difference in investment between cash-constrained and cash-rich widely held corporations.

Hypothesis 3: The 2006 dividend tax cut has a stronger effect on the decrease in the difference in investment between cash-constrained and cash-rich closely held corporations than for widely held corporations.

Empirical evidence on the effect of dividend taxes on corporate investment is scarce and mixed. Becker, Jacob, and Jacob (2013) use an international sample of listed firms over the period 1990-2008 and demonstrate that dividend and capital gains taxation affect allocation of investments. Using listed firms from the U.S., Campbell, Chyz, Dhaliwal, and Schwartz 
(2013) find similar responses to the 2003 U.S. tax cut. However, both samples include only listed firms. In contrast, Yagan (2013) finds no empirical support for this prediction around the 2003 dividend tax cut in the United States for a sample of unlisted corporations. This raises concerns that unlisted firms may have limited access to funds. This friction could potentially mute any dividend tax effect on corporate investment of unlisted firms.

\section{Data and Summary Statistics}

This study utilizes the Firm Register and Individual Database (FRIDA), maintained by Statistics Sweden. This data set comprises a full sample of Swedish corporations for the period 2000-2011 and their tax returns. The tax returns include information on tax balance sheet items and the profit and loss statement. In line with Swedish tax law, we define a nonlisted corporation as closely held if at least one of the shareholders is active and files a K-10 form in which, for example, the imputed dividend allowance is stated. Otherwise, the corporation is defined as widely held. ${ }^{11}$ The key advantage of our data is that all Swedish corporations are required to file corporate tax returns. This gives us standardized information on all Swedish corporations.

For the empirical analysis, we use the following firm-level variables. ${ }^{12}$ Our dependent variable is investment, which we define as the change in fixed assets from the previous to current periods, plus depreciation, relative to prior-year fixed assets. This variable returns a measure of additions to fixed assets as a percentage of prior-year fixed assets. As a proxy for internal resources, we use the cash-to-assets ratio. We follow the approach of Becker, Jacob,

11 In principle, corporations we define as closely held and subject to the 10 percentage point tax cut could have some passive owners who experience only a 5 percentage point tax cut. This makes our task of identifying a difference in tax responsiveness between widely and closely held corporations more difficult. However, this is not a critical issue in our study, since the vast majority (over $80 \%$ ) of closely held corporations only have active owners. When excluding closely held corporations with passive owners from the regression, we obtain very similar results. We are thus confident that our segmentation into closely and widely held corporations is precise and that a few potential passive owners in closely held corporations do not bias our results.

12 To prevent extreme values and outliers from distorting our estimates, we censor observations outside the 1st and 99th percentiles of our variables. We also exclude the few listed firms. 
and Jacob (2013) and sort our firms into quintiles based on the ratio of cash holdings to assets. To avoid tax reform affecting the assignment of treatment and control groups, we base their definition on pre-reform outcomes. We denote firms as cash-rich (cash-constrained) if they are in the top (bottom) quintile of the 3-year, industry-adjusted cash-to-assets distribution over the 2003-2005 period. We use industry-year-adjusted cash quintiles to account for differences in cash holdings across industries and over time. We do this separately for closely held corporations and widely held corporations. Using the 3-year average over the 2003-2005 period also ensures that firms cannot move across groups or enter the sample after the reform.

As firm-level control variables, we include the ratio of working capital to total assets (Working Capital), debt-to-assets ratio (Debt), sales and turnover scaled by prior-year total assets (Turnover), retained earnings scaled by prior-year total assets (Retained Earnings), growth in sales from $t-2$ to $t$ (Sales Growth), and the natural logarithm of total assets as a measure of size (Ln(Total Assets)). Variable definitions and descriptive statistics are presented in Table 2. We restrict the sample to observations for which we have information on all control variables. Since Sales Growth requires two lags, our empirical analysis uses observations from the 2002-2011 period. The final sample consists of 338,202 firm-year observations.

[Insert Table 2 about here]

\section{Empirical Analysis and Results}

\subsection{Graphical Evidence}

The simplest way to test Hypotheses 1 and 2 is to track the difference in investment by cash-rich and cash-poor firms over time. If a dividend tax cut changes investment allocation, we would observe higher investment among cash-rich firms before the reform, relative to cash-constrained firms. After the tax cut, the investment difference should then drop to a lower level. Figure 1 plots the difference in real investment between cash-rich and cash- 
constrained firms over the 2002-2011 period. We plot the difference separately for widely and closely held corporations, since the tax cut depends on ownership structure. The gray line illustrates the investment difference for widely held corporations. The black line represents closely held corporations.

\section{[Insert Figure 1 about here]}

We observe a parallel trend in the investment difference before the reform for both widely and closely held corporations. The positive difference indicates that cash-rich firms invest more than cash-poor firms. The parallel trend makes us confident that our DD estimates are not driven by other correlated, unobservable characteristics that affect allocation of investment around the tax reform. After 2006, we observe a drop in the difference in investment levels between cash-rich and cash-constrained firms. Relative to cash-rich firms, cash-poor firms invest more and, consequently, investment by these two groups converges. The implied economic magnitudes are large and statistically significant. For closely held corporations (widely held corporations), the investment difference decreases by 12 percentage points (7 percentage points) from about $19 \%(22 \%)$ to $7 \%(15 \%)$. This finding is in line with our Hypothesis 1 (Hypothesis 2).

Figure 1 also provides first indications in favor of Hypothesis 3. The response appears to be stronger among closely held corporations than among widely held corporations, since owners of closely held corporations experience the larger dividend tax cut. The difference in the response between the two sets of firms, that is, the implied triple difference, is about five percentage points.

\subsection{Regression Analysis}

To estimate the effect of the 2006 dividend tax cut on the allocation of investment, we use the following DD models: 


$$
\begin{aligned}
& \text { Inv }_{i, t}=\alpha_{0}+\alpha_{1} \cdot \text { CashPoor } \cdot \text { Reform }+\boldsymbol{\alpha} \boldsymbol{X}+\alpha_{i}+\alpha_{j, t}+\varepsilon_{i, t}, \quad \text { if CHC }=1 \\
& \text { Inv }_{i, t}=\beta_{0}+\beta_{1} \cdot \text { CashPoor } \cdot \text { Reform }+\boldsymbol{\beta} \boldsymbol{X}+\beta_{i}+\beta_{j, t}+\varepsilon_{i, t}, \quad \text { if WHC }=1 .
\end{aligned}
$$

We separately estimate each model for closely held corporations (Equation (1)) and for widely held corporations (Equation (2)). The dependent variable is $I n v_{i, t}$, which denotes real investment of firm $i$ in period $t$. Vector $\boldsymbol{X}$ denotes firm-level control variables and includes working capital to assets, retained earnings to assets, turnover to assets, debt to assets, sales growth, and firm size. ${ }^{13}$ We additionally include firm fixed effects $\left(\alpha_{i}\right.$ and $\left.\beta_{i}\right)$ and industryyear fixed effects $\left(\alpha_{j, t}\right.$ and $\left.\beta_{j, t}\right)$. Ideally, we would also control for governance variables. However, this information is not included in our data. The firm fixed effects at least control for a firm's time-invariant governance characteristics. We use a DD approach to test the hypothesis that cash-constrained firms increase investment relative to cash-rich firms after 2006. We expect the estimated DD coefficient on CashPoor - Reform to be positive, that is, $\alpha_{1}>0$ and $\beta_{1}>0$. This result would imply that the difference in investment between cashrich and cash-poor firms decreases. Note that the main effects of CashPoor and Reform are not included in the regression since they are captured by firm and industry-year fixed effects. In all regressions, our statistical inference is based on robust standard errors clustered at the firm level.

Table 3 presents the regression results for investment behavior around the 2006 tax reform in Sweden. Panel A uses the sample of closely held corporations. In Columns (1) and (2), we present average investment before and after the reform. We demean investment by year to account for time variation in average investment levels. In Column (3), we present the change

13 Since our identification of tax effects is based on a DDD approach, our reduced-form model cannot directly test all the predicted effects of the control variables in the subsamples that are derived theoretically by Egger, Ehrhardt, and Keuschnigg (2014). As these authors demonstrate, a more sophisticated empirical approach that controls for selection into different classes is necessary to obtain the coefficients for the control variables. Specifically, the authors use a threshold regression combined with an endogenous switching regression. Since our identification strategy exploits an exogenous policy shock, identification of the tax effect - the effect of interest in our study — is not biased by selection, since we base the assignment of treatment and control groups on pre-reform outcomes. 
in investment for cash-poor and cash-rich firms. Our results suggest that cash-poor firms increase investment by 6.5 percentage points after the reform. At the same time, cash-rich firms decrease investment by 6.4 percentage points. These observations are in line with the Chetty and Saez (2010) predictions. However, note that we control for no observable firm characteristics; these are simple changes in average demeaned investment over time.

Our test of Hypothesis 1 relates to the $\alpha_{1}$ coefficient. Following the dividend tax cut, we observe a change in investment behavior of closely held corporations. In our estimation without control variables, the investment difference between cash-rich and cash-poor firms decreases by 12.87 percentage points. In Column (4), we present the $\alpha_{1}$ coefficient from Equation (1), where we additionally control for observable firm characteristics, firm fixed effects, and industry-year fixed effects. The positive DD coefficient is in line with our expectations (Hypothesis 1). Cash-constrained firms increase investment compared to cashrich firms. These results are statistically significant and are large in economic terms. The investment gap between cash-rich and cash-poor firms decreases by 15.8 percentage points. In other words, the decrease in the dividend tax rate from $30 \%$ to $20 \%$ - a decrease of $33 \%$ reduced the investment gap between cash-rich and cash-poor firms by $36 \%$ of the average investment in our sample. This translates into an implied elasticity of about one. Since results are very similar in specifications with and without control variables, observable firm characteristics as well as unobservable time invariant firm characteristics cannot explain our findings. It thus appears that the 2006 tax reform has improved the allocation of investment across closely held corporations (Hypothesis 1).

\section{[Insert Table 3 about here]}

Panel B of Table 3 presents results for widely held corporations. Again, we observe that investments by cash-poor firms increase after the reform. In contrast to closely held corporations, cash-rich firms do not respond. This is in line with the simple illustrative 
example we use above, but it contrasts with the Chetty and Saez's predictions. This observation is even more surprising because we find the results to be in line with Chetty and Saez's predictions for closely held corporations, which have no or fewer agency issues than widely held corporations. However, these results are obtained by simply comparing the level of investment before and after 2006 without controlling for any firm-level characteristics or the macroeconomic trend. This single difference estimate without controls is potentially affected by observable characteristics and may, thus, only reflect a time trend. Therefore, our focus is on the DD estimate that compares the development of cash-rich relative to cash-poor firms and which controls for the overall macroeconomic trend. Also, for widely held corporations, we obtain a positive and significant DD coefficient, $\beta_{1}$. This result holds for specifications with and without control variables and is in line with Hypothesis 2. The magnitudes of the coefficients are very similar across the two specifications. Most importantly, the results are statistically and economically significant and correspond to the implied elasticity of about one for closely held corporations. Following the tax rate decrease from $30 \%$ to $25 \%$, a tax rate reduction of $16.7 \%$, the investment gap decrease amounts to 7.1 percentage points, about $16.4 \%$ of the average investment. We thus conclude that the 2006 tax reform has also improved investment allocation across widely held corporations (Hypothesis 2).

The dividend tax cut apparently changed the allocation of investment and induced more investment by cash-constrained firms relative to cash-rich firms. Note that the $\beta_{1}$ coefficient is smaller than the $\alpha_{1}$ coefficient. That is, the reallocation effect appears to be more pronounced for closely held firms than for widely held corporations. We argue that this is due to the nature of the tax reform: The dividend tax cut for closely held corporations is twice the magnitude as for widely held corporations (10 versus 5 percentage points). To test this empirically, we more closely examine change in the investment difference between cash-poor and cash-rich firms 
across these two types of corporations. More specifically, we analyze whether the 2006 dividend tax cut had a stronger effect on the decrease in the investment difference between cash-constrained and cash-rich firms for closely held corporations than for widely held corporations. We use the following DDD estimation:

$$
\begin{aligned}
\text { Inv }_{i, t}= & \gamma_{0}+\gamma_{1} \cdot \text { CashPoor } \cdot \text { Reform } \cdot \text { CHC }+\gamma_{2} \cdot \text { CashPoor } \cdot \text { CHC } \\
& +\gamma_{3} \cdot \operatorname{Reform} \cdot \text { CHC }+\gamma \boldsymbol{X}+\gamma_{i}+\gamma_{j, t}+\varepsilon_{i, t}
\end{aligned}
$$

where we again include firm-level controls $(\boldsymbol{X})$, firm fixed effects $\left(\gamma_{i}\right)$, and industry-year fixed effects $\left(\gamma_{j, t}\right)$. The coefficient of interest is the DDD estimate, $\gamma_{1}$. If our hypothesis holds, $\gamma_{1}$ will be positive. Since we additionally include interactions CashPoor . CHC and Reform . CHC,$\gamma_{1}$ captures the reallocation effect for closely held corporations in addition to the baseline reform-induced reallocation effect for widely held corporations. We present empirical results in Panel $\mathrm{C}$ of Table 3. Again, DDD estimates with and without controls are quite similar (0.0628 versus 0.0719$)$. This result is statistically and economically significant and supports Hypothesis 3. The DDD estimate corresponds to the dividend tax cut difference of 5 percentage points. To be more precise, the difference between $\alpha_{1}(0.1584)$ and $\beta_{1}(0.0713)$, that is, $\gamma_{1}(0.0719)$, reflects the difference in the tax cut between closely held corporations (10 percentage points) and widely held corporations (5 percentage points). One interpretation of our result is that a 5-percentage-point tax cut decreases the investment difference by about 7 percentage points.

From the results of our DD and DDD analysis, we conclude that dividend taxation has a large effect on allocation of corporate investment. There are heterogeneous investment responses across firms to a dividend tax cut. Our results imply that a dividend tax cut raises efficiency by improving the allocation of investment (Chetty and Saez 2010). 


\subsection{Robustness Tests}

We test the robustness of our main DDD result in several ways. One potential concern about our approach is our measure of internal resources. We use the fraction of retained earnings relative to total assets as an alternative measure of the availability of internal funds. As with cash holdings, we sort firms into quintiles of the retained earnings distribution over the 2003-2005 period prior to the reform. We demean retained earnings by industry-year. We then estimate Equation (3) to obtain the DDD estimate but substitute the Cash-Poor indicator with a Low-Retained-Earnings indicator. The coefficient estimate for the DDD are reported in Columns (1) (without controls) and (2) (with controls and fixed effects) of Table 4. The results confirm our earlier findings. The DDD estimate amounts to 0.0792 and is close to our baseline estimate of 0.0719, in which we use cash holdings as a proxy for internal resources.

The second concern relates to our investment measure. We use an alternative definition of investment activity, where we scale investments by prior-year total assets rather than total fixed assets. We re-estimate Equation (3) but use investment scaled by total assets as the dependent variable. We report the DDD coefficient without controls (with control variables and fixed effects) in Column (3) (Column (4)) of Table 4. The estimated DDD coefficients are again positive and significant. The decrease in the coefficient estimate is due to the scaling effect, since we now relate additions to fixed assets to total firm assets.

A third concern is that investment is inflated in small firms. For very small firms, minor investments could lead to very high relative investments. To address this concern, we rerun Equation (3) and include only the top $40 \%$ of the firm-size distribution. The results are similar to our previous regressions results. In fact, the coefficient estimate of 0.0898 is slightly above our baseline estimate of 0.0713 . Hence, inflated relative investments by small firms cannot explain our findings of a significant effect of a dividend tax cut on allocation of investment.

[Insert Table 4 about here] 
Another potential concern about our results is that agency costs differ across closely and widely held corporations. One may argue that even if both types of corporations experienced the same tax cut, closely held corporations would respond more strongly than widely held corporations due to differences in agency costs. Due to limited data availability, we cannot control for governance measures, such as managerial ownership share or board oversight. However, as long as these firm-specific governance characteristics are sticky over time, the inclusion of firm fixed effects should control for time-invariant governance measures. To empirically test if and how potential differences in agency costs may explain our DDD estimates, we exploit the ownership information of closely held corporations. ${ }^{14}$

We restrict our closely held corporation sample to firms with at least two owners and split the sample into firms with lower versus higher agency costs based on family ownership. For each owner, we use a family identifier that allows us to observe if the owners live in the same household. We define a Family CHC as a closely held corporation in which all owners have the same family ID and a Non-Family CHC as a closely held corporation with different family IDs across owners. We argue that agency costs are lower for Family CHCs than for NonFamily CHCs.

We rerun Equations (1) to (3) to obtain the DD and DDD estimates. Table 5 presents the coefficient estimates for the Family CHC sample (Panel A) and Non-Family CHC sample (Panel B) and the resulting triple difference (Panel C). The results show that Family CHCs as well as Non-Family CHCs respond to the 2006 tax reform. Both samples comprise closely held corporations that experience a 10-percentage-point tax cut. Consistent with our main results, we find that cash-poor firms increase investment relative to cash-rich firms for both Family CHCs and Non-Family CHCs. Finally, the DDD estimate reflects differences in agency costs across Family CHCs and Non-Family CHCs. Since the DDD coefficient is not

14 Since we do not have this ownership information for widely held corporations, this test can only be executed for closely held corporations. 
significant at any conventional level ( $t$-statistic $=0.79$ ), we are confident that the average baseline DDD estimate from Table 3 is not (fully) explained by differences in agency costs between closely and widely held corporations that are not captured by firm fixed effects in our DDD approach.

\section{[Insert Table 5 about here]}

\subsection{Effect of 2006 Reform on Equity Issuances by Cash-Constrained Firms}

We next turn to two potential explanations for the observed effect that dividend taxation affects corporate investment allocation. Our first explanation refers to the source of financing. The underlying assumption of the old view is that cash-constrained firms finance new investments with new equity (Harberger 1962, 1966, Feldstein 1970, Poterba and Summers 1985). The dividend tax cut reduces the costs of financing investments with equity and makes it more attractive for an investor to invest new equity, since the investor's after-tax dividends increase for a given dividend distribution from the firm. In a DD framework, we test to what extent this assumption holds empirically. We would expect cash-constrained firms to raise more equity after the 2006 dividend tax cut relative to cash-rich firms.

We present the regression results in Table 6. Again, we run this regression separately for closely held and widely held corporations. Results are in line with the underlying assumptions of the old view. Cash-constrained firms are able to raise new capital and increase their nominal equity after the reform compared to cash-rich firms. Results are significant in specifications both with and without control variables. For both cash-poor, widely held and cash-poor, closely held corporations, the nominal equity-to-assets ratio increases by 1.5 percentage points relative to cash-rich firms. This is equivalent to an increase of about $11 \%$ of the average nominal equity-to-assets ratio of $14.5 \%$ in our sample. Therefore, one explanation for the finding that investment by cash-rich and cash-poor firms converges after the dividend tax cut is that cash-constrained firms increased financing with new equity. 
[Insert Table 6 about here]

We next test whether the debt margin of cash-poor versus cash-rich firms also responds to the 2006 tax reform. The dividend tax cut now makes external equity cheaper and thus the cost difference between external equity and debt becomes smaller and debt should decrease (see also Faccio and Xu 2013). In our setting, we expect cash-poor firms to reduce debt-toequity ratios following the tax reform relative to cash-rich firms. If, however, the increase in nominal equity implies that a firm has more collateral and consequently a higher credit line, the debt-to-equity ratio may not respond at all, since firms extend the equity margin as well as the debt margin.

To test whether firms can also extend the debt margin, we repeat the test from Table 6 but use the debt-to-equity ratio as dependent variable. If the debt and equity margins respond similarly, we would not observe a change in the debt-to-equity ratios. However, we find significant reform responses in line with Faccio and Xu's (2013) results for listed firms. The negative DD estimates in Table 7 show that the 2006 dividend tax cut in Sweden led to a reduction in the debt-to-equity ratios of cash-poor firms relative to cash rich-firms. This effect is consistent with the view that the tax advantage of debt decreases if the dividend tax rate is reduced. Taken together, the positive DD coefficients in Table 6 and the negative DD coefficients in Table 7 imply that cash-poor firms increase funds more through the external equity channel and less through raising new external debt.

[Insert Table 7 about here]

\subsection{Effect of 2006 Reform on Dividend Payout by Cash-Rich, Closely Held Corporations}

The second explanation for the effect that dividend taxation has on allocation of corporate investment refers to the use of internal funds in firms. The Chetty and Saez (2010) model predicts that cash-rich firms decrease investments and increase dividends. Hence, the use of (some) funds in cash-rich firms changes from investment to dividend payout. Because we do 
not expect cash-poor firms to increase dividends, the investment difference between cash-poor and cash-rich firms decreases. Our data, unfortunately, only include information on dividends of closely held corporations (see, also, Jacob, Michaely, and Alstadsæter 2014). Therefore, we can test only the Chetty and Saez prediction for closely held corporations. We use a DD approach and test whether cash-rich firms increase dividend payouts after the reform. Table 8 reports the DD coefficient Reform*Cash Rich, which captures the increase in dividend payout of cash-rich firms relative to cash-poor firms.

We use two alternative dependent variables. In Columns (1) and (2) of Table 8, we use an indicator variable, Dividend Payer, which is equal to 1 if the firm pays a dividend in the current year, and zero otherwise. In Columns (3) and (4), we use the ratio of dividend payout to prior-year total assets (Dividend-to-Asset Ratio) as the dependent variable. Our DD estimates show that relative to a cash-poor firm, the likelihood that a cash-rich firm pays a dividend after the tax reform increases by 4.3 percentage points-about $11 \%$ of the sample average. This effect is much stronger for the level of dividend payout. Relative to cash-poor firms, the dividend-to-asset ratio of cash-rich firms increases by 2.3 percentage points, or about the sample average. Such a large response is not surprising, since, for closely held firms, dividend taxation is often the only friction in the payout decision process (Jacob, Michaely and Alstadsæter 2014).

The results for closely held corporations support the empirical predictions of Chetty and Saez (2010). Following a dividend tax cut, cash-poor firms invest more. Cash-rich firms invest less and increase dividend payout. Overall, the allocation of investment improves as investment between cash-poor and cash-rich firms converges. This decrease can be explained by (i) higher equity issuance by cash-poor firms and (ii) by higher dividend payouts by cashrich firms.

[Insert Table 8 about here] 


\subsection{Effect of 2006 Reform on Firm Growth}

One implication of Chetty and Saez's (2010) model is that a dividend tax cut improves the allocation of investment as funds and, consequently, investments are shifted from cash-rich to financially constrained firms. Our main test from Table 3 shows that the investment gap between cash-rich and cash-poor firms decreased around the 2006 dividend tax cut. However, does this change in investment allocation across firms also translate into firm growth? We therefore test if cash-poor firms also experienced higher growth in sales and turnover after the reform than cash-rich firms. We measure firm growth through turnover scaled by total assets. Table 9 presents the regression results from estimating our main DD and DDD models, Equations (1) to (3), with turnover scaled by the prior year's total assets as the dependent variable. We find positive and significant DD and DDD estimates. Again, the results are economically significant. For example, for closely held corporations with a dividend tax cut from $30 \%$ to $20 \%$, or $33 \%$ of the pre-reform level, the turnover of cash-poor firms increased by $23 \%$ relative to that of cash-rich firms. It thus appears as if the investment activity of cashpoor firms relative to cash-rich firms (see Table 3) also translates into higher turnover and sales.

[Insert Table 9 about here]

\section{Conclusion}

We generate, using proprietary administrative tax data on all Swedish unlisted corporations, empirical evidence that dividend taxes affect investment. Our identification strategy exploits heterogeneous investment responses to the 2006 dividend tax cut using difference-in-difference as well as triple-difference estimators. We find that the reform improved allocation of investment in capital stock across firms. Relative to cash-rich firms, cash-constrained corporations increase investment following the reform. Investments thus appear to have shifted from firms with sufficient internal funds to firms with investment 
opportunities that, prior to the reform, did not have the necessary funds to carry out the investment. These results are consistent with prior theoretical predictions that dividend tax reforms spur heterogeneous investment responses across firms (Chetty and Saez 2010).

Allocation of investment is improved through at least two channels. First, following a dividend tax cut, cash-constrained firms increase nominal equity as costs of external equity decrease. Second, cash-rich firms increase dividend payout after the dividend tax cut. High dividend taxation appears to lock in funds in cash-rich firms. Thus, both channels (partly) explain why investment activities of cash-constrained firms and cash-rich firms converge after a dividend tax cut.

One implication of our results is that dividend taxes are a substantial cost to some firms with respect to financing investment. By reducing dividend taxes, governments can improve the allocation of investment across firms. Efficiency would then increase (Chetty and Saez 2010). It appears as if larger gains from a capital tax reform can be obtained from policy changes targeted at constrained firms, for example, by introducing a partial deduction for dividends paid (e.g., Auerbach 2002). ${ }^{15}$ However, a dividend tax reduction potentially comes at the cost of income shifting across tax bases (see, e.g., Slemrod 1995, Gordon and Slemrod 2000, Alstadsæter and Jacob 2014, Harju and Matikka 2014). This potential trade-off should be taken into account when developing reform proposals. scheme was called the Annell deduction (see King and Fullerton 1984, Auerbach 2002). 


\section{References}

Alstadsæter, Annette, and Martin Jacob (2012): Income Shifting in Sweden-An empirical evaluation of the 3:12 rules. Report to the Expert Group for Public Economics, Ministry of Finance, Stockholm.

Alstadsæter, Annette, and Martin Jacob (2014): Dividend taxes and income shifting. FAccT Center working paper No. 07/2012.

Apel, Mikael, and Jan Södersten (1999): Personal taxation and investment incentives in a small open economy. International Tax and Public Finance, 6, 79-88.

Auerbach, Alan J. (1979): Wealth maximization and the cost of capital. Quarterly Journal of Economics, 93, 433-446.

Auerbach, Alan J. (2002): Taxation and corporate financial policy. Handbook of Public Economics, 3, 1251-1292.

Auerbach, Alan J., and Kevin A. Hassett (2002): On the marginal source of investment funds. Journal of Public Economics, 87, 205-232.

Auerbach, Alan J., and Kevin A. Hassett (2006): Dividend taxes and firm valuation: New evidence. American Economic Review, 96, 119-123.

Bradford, David F. (1981): The incidence and allocation effects of a tax on corporate distributions. Journal of Public Economics, 15, 1-22.

Becker, Bo, Marcus Jacob, and Martin Jacob (2013): Payout taxes and the allocation of investment. Journal of Financial Economics, 107, 1-24.

Campbell, John L., James Chyz, Dan S. Dhaliwal, and William C. Schwartz (2013): Did the 2003 Tax Act Increase Capital Investments by Corporations? Journal of American Taxation Association, 35, 33-63.

Chetty, Raj, Joseph Rosenberg, and Emmanuel Saez (2007): The effects of taxes on market responses to dividend announcements and payments: What can we learn from the 2003 dividend tax cut? In: Alan J. Auerbach, James R. Hines, and Joel B. Slemrod (Eds.), Taxing corporate income in the 21st Century, Cambridge: Cambridge University Press, 1-33.

Chetty, Raj, and Emmanuel Saez (2005): Dividend taxes and corporate behavior: Evidence from the 2003 dividend tax cut. Quarterly Journal of Economics, 120, 791-833. 
Chetty, Raj, and Emmanuel Saez (2010): Dividend and corporate taxation in an agency model of the firm. American Economic Journal: Economic Policy, 2, 1-31.

Edin, P.-O., I. Hansson and S.-O. Lodin (2005): Reformerad ägarbeskattning: effektivitet, prevention, legitimitet. Swedish Ministry of Finance.

Egger, Peter, Katharina Erhardt, and Christian Keuschnigg (2014): Personal Income Taxes, Corporate Profit Taxes, and the Heterogeneous Tax Sensitivity of Firm-Level Investments. Working Paper.

Faccio, Mara and Jin Xu (2013): Taxes and capital structure. Journal of Financial and Quantitative Analysis, forthcoming.

Feldstein, Martin S. (1970): Corporate taxation and dividend behaviour. Review of Economic Studies, 37, 57-72.

Gordon, Roger H. and Joel B. Slemrod (2000): Are “real” responses to taxes simply income shifting between corporate and personal tax base? In: Joel B. Slemrod (Ed.), Does Atlas shrug? The economic consequences of taxing the rich, Cambridge: Harvard University Press. Russell Sage Foundation, 240-288.

Government Bill 2004/05:1 (Regeringens proposition 2004/05:1), Budget Bill for 2005, Swedish Ministry of Finance.

Government Bill 2005/06:40 (Regeringens proposition 2005/06:40), Reformerade beskattningsregler för ägare i fåmansföretag , Swedish Ministry of Finance.

Government Bill 2006/07:1 (Regeringens proposition 2006/07:1), Budget Bill for 2007, Swedish Ministry of Finance.

Harberger, Arnold C. (1962): The incidence of the corporation income tax. Journal of Political Economy, 70, 215-240.

Harberger, Arnold C. (1966): Efficiency effects of taxes on income from capital. In: Marian Krzyzaniak (Ed.), Effects of corporation income tax. Detroit: Wayne State University Press. Harju, Jarkko and Tuomas Matikka (2014): The Elasticity of Taxable Income and IncomeShifting between Tax Bases: What is 'Real' and What is Not?, Working Paper.

Jacob, Martin, Roni Michaely, and Annette Alstadsæter (2014): Taxation and Dividend Policy: The Muting Effect of Diverse Ownership Structure. Working paper. 
Jacob, Martin, and Jan Södersten (2013): Mitigating shareholder taxes in small open economies? Finnish Economic Papers, 26, 1-12.

King, Mervyn A. (1977): Public Policy and the Corporation. London: Chapman and Hall.

King, Mervyn A. and Don Fullerton (1984): The Taxation of Income from Capital: A Comparative Study of the United States, the United Kingdom, Sweden, and Germany. (University of Chicago Press, Chicago).

Korinek, Anton, and Joseph E. Stiglitz (2009): Dividend taxation and intertemporal tax arbitrage. Journal of Public Economics, 93, 142-159.

Lewellen, Jonathan and Katharina Lewellen (2006): Internal Equity, Taxes, and Capital Structure. Working Paper, Dartmouth College.

Lindhe, Tobias, and Jan Södersten (2012): The Norwegian shareholder tax reconsidered. International Tax and Public Finance, 19, 424-441.

Michaely, Roni and Michael R. Roberts (2012): Corporate Dividend Policies: Lessons from Private Firms. Review of Financial Studies, 25, 711-746.

Poterba, James M. (2004): Taxation and corporate payout policy. American Economic Review, 94, 171-175.

Poterba, James M., and Lawrence H. Summers (1985): The economic effects of dividend taxation. In: Edward Altman and Marti Subrahmanyam (Eds.), Recent advances in corporate finance. Homewood, IL: Dow Jones-Irwin Publishing, 227-284.

Slemrod, Joel B. (1995): Income creation or income shifting? Behavioral responses to the Tax Reform Act of 1986. American Economic Review, 85, 175-180.

Yagan, Danny (2013): Capital tax reform and the real economy: The effects of the 2003 dividend tax cut. Working paper. 


\section{Figure 1: Difference in Investment between High-Cash Flow and Low-Cash Flow Firms,}

2002-2011

This figure shows the difference in investment between low-cash flow firms and high-cash flow firms. We use the quintile of the four-year average cash flow-to-assets ratio over the period 2002-2005 as a measure of cash constraints. We denote the bottom (top) quintile as low-cash (high-cash) firms. We separately present the difference for closely held corporations (black line) and for widely held corporations (gray line).

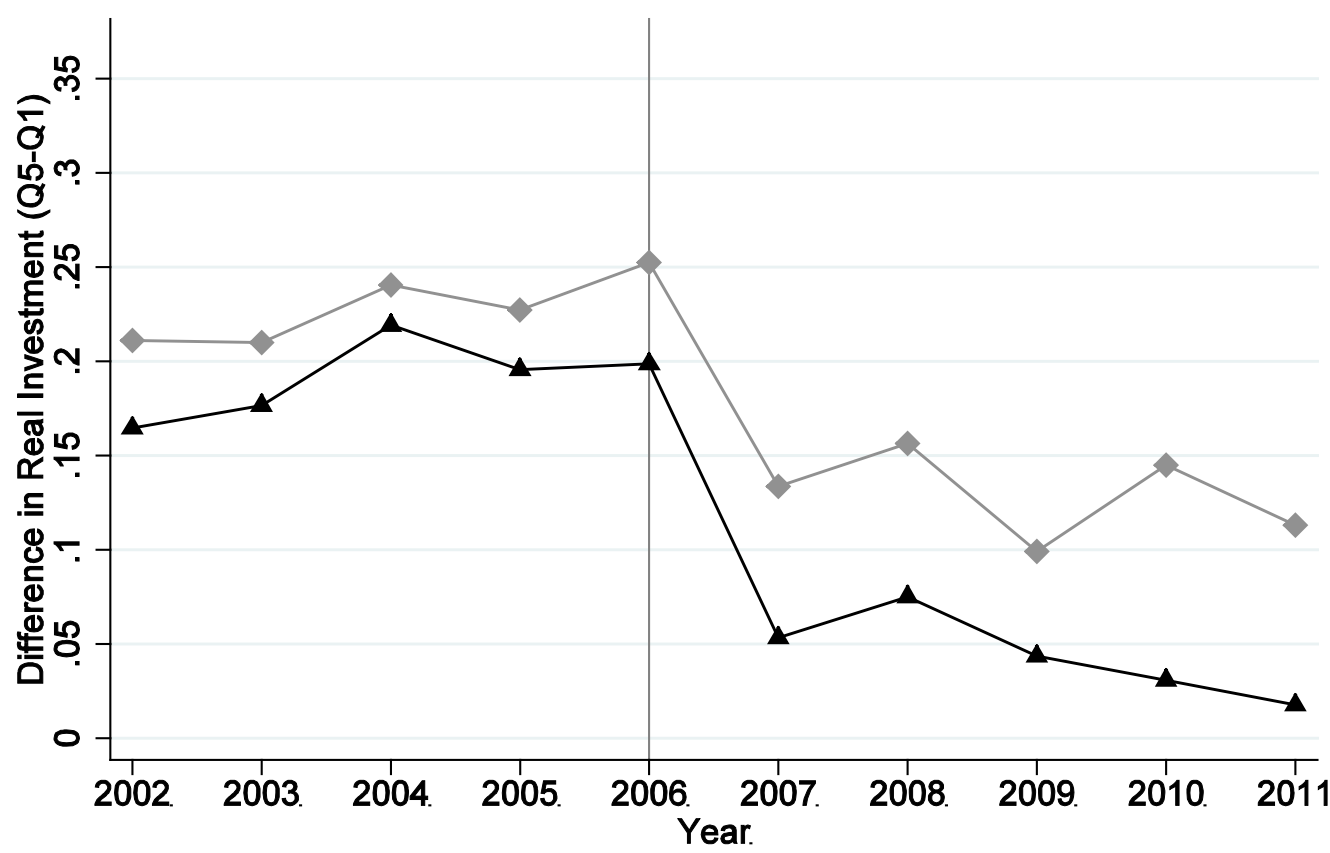


Table 1: Tax Rates on Corporate Income and Dividends Around 2006

\begin{tabular}{|c|c|c|c|}
\hline \multirow[b]{2}{*}{ Period } & \multirow{2}{*}{$\begin{array}{l}\text { Corporate } \\
\text { income tax }\end{array}$} & \multicolumn{2}{|c|}{ Dividend tax } \\
\hline & & $\begin{array}{l}\text { Closely held } \\
\text { corporations* }\end{array}$ & $\begin{array}{l}\text { Widely held } \\
\text { corporations }\end{array}$ \\
\hline 2000-2005 & 28 & 30 & 30 \\
\hline 2006-2011 & $28 / 26.3^{* *}$ & 20 & 25 \\
\hline
\end{tabular}

Table 2: Summary Statistics of Main Variables

This table presents descriptive statistics of our main variables over the 2000-2011 period. Investment is the change in fixed assets from $t-1$ to $t$ plus depreciation relative to prior-year fixed assets. Nominal Equity is the SEK nominal equity amount scaled by prior-year total assets. Dividend-to-Asset Ratio is the ratio of dividend payout to prior-year total assets. Dividend Payer is a dummy variable equal to 1 if the closely held corporation (CHC) distributes dividends. Information on dividend payout is restricted to closely held corporations. CHC is a dummy variable equal to 1 if the firm is closely held, 0 otherwise. Cash is the ratio of cash holdings to prior-year total assets. Working Capital is SEK working capital amount in year $t$ scaled by prior-year total assets. Debt is the ratio of longterm and short-term liabilities to prior-year total assets. Turnover is SEK sales and turnover in year $t$ scaled by prioryear total assets. Retained Earnings is SEK retained earnings amount in year $t$ scaled by prior-year total assets. Sales Growth is the percentage change in turnover from $t$-2 to $t$. We use the natural logarithm of total assets (in $\mathrm{SEK})$ as the measure of size ( $\operatorname{Ln}$ (Total Assets)).

\begin{tabular}{lcccccc}
\hline Variable & $\mathbf{N}$ & Mean & $\begin{array}{c}\text { Standard } \\
\text { Deviation }\end{array}$ & $\begin{array}{c}\mathbf{2 5}^{\text {th }} \\
\text { Percentile }\end{array}$ & Median & $\begin{array}{c}\mathbf{7 5}^{\text {th }} \\
\text { Percentile }\end{array}$ \\
\hline Investment & 338,202 & 0.4341 & 1.2288 & 0.0000 & 0.0473 & 0.3926 \\
Nominal Equity & 328,409 & 0.1447 & 0.1798 & 0.0344 & 0.0800 & 0.1798 \\
Dividend-to-Asset Ratio & 201,647 & 0.0240 & 0.0572 & 0.0000 & 0.0000 & 0.0199 \\
Dividend Payer & 201,647 & 0.3771 & 0.4847 & 0.0000 & 0.0000 & 1.0000 \\
CHC & 338,202 & 0.7333 & 0.4422 & 0.0000 & 1.0000 & 1.0000 \\
Cash & 338,202 & 0.2994 & 0.3419 & 0.0046 & 0.1589 & 0.5412 \\
Debt & 338,202 & 0.5509 & 0.3740 & 0.2606 & 0.5172 & 0.7812 \\
Working Capital & 338,202 & 0.4366 & 0.3501 & 0.1558 & 0.3628 & 0.6587 \\
Turnover & 338,202 & 1.7590 & 1.6727 & 0.5711 & 1.4245 & 2.4580 \\
Retained Earnings & 338,202 & 0.2355 & 0.3100 & 0.0477 & 0.2014 & 0.4267 \\
Sales Growth & 338,202 & -0.0272 & 0.6006 & -0.1715 & 0.0230 & 0.2067 \\
Ln(Total Assets) & 338,202 & 14.6489 & 1.5876 & 13.5386 & 14.5116 & 15.5980 \\
\hline
\end{tabular}


Table 3: Dividend Taxes and Corporate Investment, 2002-2011

This table presents regressions results for investment behavior around the 2006 tax reform in Sweden. Panel A uses the sample of closely held corporations and Panel B uses widely held corporations. We present DD estimates around the reform. We demean investments by average investment in the respective year. We compare low-cash flow firms and high-cash flow firms. We use the quintile of the four-year average cash flow-to-assets ratio over the period $2002-$ 2005 as a measure of cash constraints. We denote the bottom (top) quintile as cash-poor (cash-rich) firms. In Column (4), we present DD estimates and DDD estimates with control variables. The dependent variable is investment. We define investment as the difference between current fixed assets and prior-year fixed assets plus depreciation, scaled by prior-year fixed assets. As control variables, we include working capital to assets, retained earnings to assets, turnover to assets, debt to assets, and sales growth. We further include industry-year fixed effects and firm fixed effects. $* * *, * *$, and $*$ denote significance at the $1 \%, 5 \%$, and $10 \%$ levels, respectively. We report robust standard errors clustered at the firm level in parentheses.

\begin{tabular}{|c|c|c|c|c|}
\hline & $\begin{array}{l}\text { Pre-Reform } \\
\text { 2002-2005 } \\
\text { (1) }\end{array}$ & $\begin{array}{l}\text { Post-Reform } \\
\text { 2006-2011 } \\
\text { (2) }\end{array}$ & $\begin{array}{l}\text { Time Difference } \\
\text { for Group } \\
\text { (3) }\end{array}$ & $\begin{array}{l}\text { Estimates with Controls } \\
\text { (4) }\end{array}$ \\
\hline Cash-Poor Firms & -0.1294 & -0.0647 & $\begin{array}{c}0.0647 * * * \\
(0.0060)\end{array}$ & \\
\hline Cash-Rich Firms & 0.1245 & 0.0605 & $\begin{array}{c}-0.0640 * * * \\
(0.0075) \\
\end{array}$ & \\
\hline $\begin{array}{l}\text { Difference Cash-Rich- } \\
\text { Cash-Rich in } t\end{array}$ & $\begin{array}{c}-0.2539 * * * \\
(0.0069)\end{array}$ & $\begin{array}{c}-0.1253 * * * \\
(0.0073)\end{array}$ & & \\
\hline
\end{tabular}

$\begin{array}{ccc}0.1287 * * * & \mathbf{0 . 1 5 8 4} * * * \\ \text { DD Estimate } & (0.0096) & (0.0119)\end{array}$

Panel B: Widely Held Corporations-5-Percentage-Point Dividend Tax Cut

\begin{tabular}{lcccc}
\hline & $\begin{array}{c}\text { Pre-Reform } \\
2002-2005\end{array}$ & $\begin{array}{c}\text { Post-Reform } \\
2006-2011\end{array}$ & $\begin{array}{c}\text { Time Difference } \\
\text { for Group }\end{array}$ & Estimates with Controls \\
\hline Cash-Poor Firms & -0.1686 & -0.1027 & $0.0659 * * *$ & $(0.0108)$ \\
& & & -0.0008 & \\
Cash-Rich Firms & 0.1051 & 0.1043 & $(0.0125)$ & \\
& & & & \\
\hline Difference Cash-Rich- & $-0.2738^{* * *}$ & $-0.2071^{* * *}$ & & \\
Cash-Rich in $t$ & $(0.0125)$ & $(0.0120)$ & & \\
\hline
\end{tabular}

DD Estimate

Panel C: Difference between Closely Held Corporations and Widely Held Corporations

DDD Estimate 


\section{Table 4: Dividend Taxes and Corporate Investment, Robustness tests}

This Table reports difference-in-difference-in-difference estimates (DDD estimates) for three sets of robustness tests. Columns (1) and (2) use retained earnings as a proxy for financial constraints. We denote the bottom (top) quintile of the retained earnings distribution as constrained (non-constrained) firms. Columns (3) and (4) control for scaling effects and use the ratio of investments to total assets. Columns (5) and (6) restrict the sample to firms in the top 40\% of the firm-size distribution. Columns (2), (4), and (6) include control variables, industry-year fixed effects, and firm fixed effects. ${ }^{* *}, * *$, and $*$ denote significance at the $1 \%, 5 \%$, and $10 \%$ levels, respectively. We report robust standard errors clustered at the firm level in parentheses.

\begin{tabular}{ccc}
$\begin{array}{c}\text { Quintiles of Retained } \\
\text { Earnings }\end{array}$ & $\begin{array}{c}\text { Control for Scaling } \\
\text { by Total Assets }\end{array}$ & $\begin{array}{c}\text { Robustness to Firm } \\
\text { Size }\end{array}$ \\
\hline
\end{tabular}

(1) (2)

\begin{tabular}{lcccccc} 
DDD Estimate & $0.0676^{* * *}$ & $0.0792^{* * *}$ & $0.0070^{* * *}$ & $0.0059^{* *}$ & $0.0438 * *$ & $0.0898^{* * *}$ \\
& $(0.0167)$ & $(0.0235)$ & $(0.00019)$ & $(0.0024)$ & $(0.0200)$ & $(0.0309)$ \\
\hline Controls & No & Yes & No & Yes & No & Yes \\
Firm FE & No & Yes & No & Yes & No & Yes \\
Industry-Year FE & No & Yes & No & Yes & No & Yes \\
Observations & 344,784 & 344,783 & 328,132 & 328,132 & 152,875 & 152,875 \\
R-squared & $0.10 \%$ & $20.02 \%$ & $0.65 \%$ & $26.03 \%$ & $1.33 \%$ & $22.52 \%$ \\
\hline
\end{tabular}

Table 5: Dividend Taxes and Corporate Investment, Family vs. non-Family Firms This table presents the regressions results for investment behavior around the 2006 tax reform in Sweden. Panel A uses the sample of family CHCs and Panel B uses non-family CHCs. We present DD estimates around the reform. We define a family $\mathrm{CHC}$ as a $\mathrm{CHC}$ whose owners all have the same family ID, since the family ID is the same for spouses and their children living the same household. If owners have different family identifiers, we denote this firm as a non-family CHC. We restrict the sample to firms with at least two owners. We demean investments by the average investment in the respective year. We compare low- and high-cash flow firms. We use the quintile of the ratio of the four-year average cash flow to assets over the period 2002-2005 as a measure of cash constraint. We denote the bottom (top) quintile as cash-poor (cash-rich) firms. In Column (2), we present the DD estimates and DDD estimates with control variables. The dependent variable is investment. We define investment as the difference between current fixed assets and the prior year's fixed assets plus depreciation, scaled by the prior year's fixed assets. For control variables, we include the ratios of working capital to assets, of retained earnings to assets, of turnover to assets, and of debt to assets and sales growth. We further include industry-year fixed effects and firm fixed effects. ***, **, and * denote significance at the $1 \%, 5 \%$, and $10 \%$ levels, respectively. We report robust standard errors clustered at the firm level in parentheses.

\section{Estimates without Controls}

(1)
Estimates with Controls (2)

Panel A: Family Closely Held Corporations

\begin{tabular}{lcc}
\hline \multirow{2}{*}{ DD Estimate } & $0.0817 * * *$ & $0.1340 * * *$ \\
& $(0.0268)$ & $(0.0368)$ \\
\hline
\end{tabular}

Panel B: Non-Family Closely Held Corporations

\begin{tabular}{lcc}
\hline \multirow{2}{*}{ DD Estimate } & $0.0787^{* * *}$ & $0.1098^{* * * *}$ \\
& $(0.0200)$ & $(0.0281)$ \\
\hline
\end{tabular}

Panel C: Difference between Family and Non-Family Closely Held Corporations

\begin{tabular}{lcc}
\hline \multirow{2}{*}{ DDD Estimate } & 0.0030 & 0.0337 \\
& $(0.0335)$ & $(0.0425)$ \\
\hline
\end{tabular}


Table 6: Dividend Taxes, Cash Holdings, and Nominal Equity

This table presents the regression results of equity behavior around the 2006 tax reform in Sweden. The dependent variable is the ratio of nominal equity to total assets. As control variables, we include working capital to assets, retained earnings to assets, turnover to assets, debt to assets, and sales growth. We further include industry-year fixed effects and firm fixed effects. ***, **, and * denote significance at the $1 \%, 5 \%$, and $10 \%$ levels, respectively. We report robust standard errors clustered at the firm level in parentheses.

\begin{tabular}{lcccccc}
\hline & \multicolumn{2}{c}{ Closely Held Corporations } & & \multicolumn{2}{c}{ Widely Held Corporations } \\
\cline { 2 - 3 } \cline { 6 - 6 } & $(1)$ & $(2)$ & & $(3)$ & $(4)$ \\
\hline Reform*Cash Poor & $0.0323^{* * *}$ & $0.0153^{* * *}$ & & $0.0579 * * *$ & $0.0146^{* * *}$ \\
& $(0.0015)$ & $(0.0010)$ & & $(0.0031)$ & $(0.0022)$ \\
\hline Firm Controls & No & Yes & & No & Yes \\
Firm FE & No & Yes & & No & Yes \\
Industry-Year FE & No & Yes & & No & Yes \\
Observations & 241,570 & 241,570 & & 86,839 & 86,839 \\
R-squared & $4.61 \%$ & $88.10 \%$ & & $3.88 \%$ & $91.13 \%$ \\
\hline
\end{tabular}

\section{Table 7: Dividend Taxes, Cash Holdings, and Debt-to-Equity Ratios}

This table presents the regression results for capital structure around the 2006 tax reform in Sweden. The dependent variable is the ratio of total debt to nominal equity. As control variables, we include the ratios of working capital to assets, of retained earnings to assets, and of turnover to assets and sales growth. We further include industry-year fixed effects and firm fixed effects. ${ }^{* * *}, * *$, and $*$ denote significance at the $1 \%$, 5\%, and $10 \%$ levels, respectively. We report robust standard errors clustered at the firm level in parentheses.

\begin{tabular}{lccccc}
\hline & \multicolumn{2}{c}{ Closely Held Corporations } & & \multicolumn{2}{c}{ Widely Held Corporations } \\
\cline { 2 - 3 } \cline { 5 - 6 } & $(1)$ & $(2)$ & & $(3)$ & $(4)$ \\
\hline Reform*Cash Poor & $-1.4102^{* * *}$ & $-1.3255^{* * *}$ & & $-1.3996^{* * *}$ & $-0.8776^{* * *}$ \\
& $(0.0536)$ & {$[0.0572]$} & & $(0.1197)$ & $(0.1496)$ \\
\hline Firm Controls & No & Yes & & No & Yes \\
Firm FE & No & Yes & & No & Yes \\
Industry-Year FE & No & Yes & & No & Yes \\
Observations & 236,746 & 236,746 & & 85,492 & 85,492 \\
R-squared & $18.23 \%$ & $71.99 \%$ & & $8.02 \%$ & $73.45 \%$ \\
\hline
\end{tabular}


Table 8: Dividend Taxes, Cash Holdings, and Dividend Payout

This table presents regression results of payout behavior of closely held corporations around the 2006 tax reform in Sweden. The dependent variable is a dummy variable equal to 1 if the firm pays dividends (Columns 1 and 2). In Columns (3) and (4), we use the ratio of dividends to prior-year total assets as the dependent variable. As control variables, we include working capital to assets, retained earnings to assets, turnover to assets, debt to assets, and sales growth. We further include industry-year fixed effects and firm fixed effects. $* * *, * *$, and * denote significance at the $1 \%, 5 \%$, and $10 \%$ levels, respectively. We report robust standard errors clustered at the firm level in parentheses.

\begin{tabular}{|c|c|c|c|c|}
\hline & \multicolumn{2}{|c|}{ Dividend Payer } & \multicolumn{2}{|c|}{ Dividend-to-Asset Ratio } \\
\hline & (1) & $(2)$ & (3) & $(4)$ \\
\hline Reform*Cash Rich & $\begin{array}{c}0.0662 * * * \\
(0.0048)\end{array}$ & $\begin{array}{c}0.0426^{* * *} \\
(0.0055)\end{array}$ & $\begin{array}{c}0.0260 * * * \\
(0.0005)\end{array}$ & $\begin{array}{c}0.0234 * * * \\
(0.0007)\end{array}$ \\
\hline Firm Controls & No & Yes & No & Yes \\
\hline Firm FE & No & Yes & No & Yes \\
\hline Industry-Year FE & No & Yes & No & Yes \\
\hline Observations & 201,647 & 201,647 & 201,647 & 201,647 \\
\hline R-squared & $6.69 \%$ & $52.87 \%$ & $10.17 \%$ & $46.62 \%$ \\
\hline
\end{tabular}

\section{Table 9: Dividend Taxes and Firm Growth}

This table presents the regressions results for firm growth around the 2006 tax reform in Sweden. Panel A uses the sample of CHCs and Panel B uses widely held corporations. We present the DD estimates around the reform. We compare low and high-cash flow firms. We use the quintile of the ratio of the four-year average cash flow to assets over the period 2002-2005 as a measure of cash constraint. We denote the bottom (top) quintile as cash-poor (cash-rich) firms. In Column (4), we present the DD and DDD estimates with control variables. The dependent variable is the ratio of turnover to assets. We define investment as the difference between current fixed assets and the prior year's fixed assets plus depreciation, scaled by the prior year's fixed assets. As control variables, we include the ratios of working capital to assets, of retained earnings to assets, and of debt to assets. We further include industry-year fixed effects and firm fixed effects. $* * *, * *$, and * denote significance at the $1 \%$, 5\%, and $10 \%$ levels, respectively. We report robust standard errors clustered at the firm level in parentheses.

\section{Estimates without \\ Controls}

(1)

\section{Estimates with \\ Controls}

(2)

Panel A: Closely Held Corporations

\begin{tabular}{lcc}
\hline \multirow{2}{*}{ DD Estimate } & $0.3120^{* * *}$ & $0.4112^{* * *}$ \\
& $(0.0137)$ & $(0.0113)$ \\
\hline
\end{tabular}

Panel B: Widely Held Corporations

\begin{tabular}{lcc}
\hline \multirow{2}{*}{ DD Estimate } & $0.1684^{* * *}$ & $0.2820^{* * *}$ \\
& $(0.0268)$ & $(0.0207)$ \\
\hline
\end{tabular}

Panel C: Difference between Closely Held and Widely Held Corporations

\begin{tabular}{lcc}
\hline \multirow{2}{*}{ DDD Estimate } & $0.2954 * * *$ & $0.1255^{* * *}$ \\
& $(0.0238)$ & $(0.0202)$ \\
\hline
\end{tabular}

